\title{
A virus survey of New Zealand fresh, process and seed potato crops during 2010-11
}

\author{
J.D. Fletcher \\ The New Zealand Institute for Plant E Food Research Limited, Private Bag 4704, \\ Christchurch 8140, New Zealand \\ Corresponding author: John.fletcher@plantandfood.co.nz
}

\begin{abstract}
A survey of 35 potato crops for potato viruses X, Y, S, M, A and leafroll was completed in three regions of New Zealand. PVS was the most widespread virus, with incidences of up to $100 \%$ in most crops. PVM and PVA were present in around one-third of crops, with PVM incidence at $100 \%$ in 11 crops. The incidence of PVA was always below $3.5 \%$. PVYN ${ }^{\mathrm{N}}$ was present in $17 \%$ of crops. Within crops, PVY incidence reached $100 \%$ in two crops but in the remaining five crops was $50 \%$ or lower. Potato leafroll virus was detected in only five crops at $2 \%$ or less, and similarly PVX in three crops at $1 \%$ incidence. Over 20 years PVS has increased in incidence whereas PVX, PVY, PVYN and PLRV have decreased. Of some concern is the apparent increase in the incidence of PVM. Likely reasons for these changes in virus incidence are discussed along with future virus management recommendations.
\end{abstract}

Keywords survey, Potato virus $X$, Potato virus $Y$, Potato virus S, Potato virus $M$, Potato virus A, Potato leafroll virus, PVYN.

\section{INTRODUCTION}

Potatoes in New Zealand are grown for the market as fresh (3548 ha), processing into other potato products (5926 ha) or seed potatoes (1194 ha) (Potatoes New Zealand 2011). Potato is the most valuable vegetable crop to New Zealand, both as a commodity and as an export product. In 2010 the domestic sales value was $\$ 282 \mathrm{M}$ and the export value was $\$ 100 \mathrm{M}$. Consequently, the health of this important crop is of concern to the industry, growers, merchants and processors. While the damaging disease and pest combination of Candidatus Liberibacter solanacearum and its vector the tomato potato psyllid have challenged potato crop health recently in New Zealand, it is also important not to neglect past disease problems and to monitor their status periodically.
With this in mind, a virus disease survey was undertaken specifically to determine the incidence of Potato virus $Y$ (PVY) in fresh, process and seed crops. Three strains of PVY are present in New Zealand: $\mathrm{PVY}^{\mathrm{O}}, \mathrm{PVY}^{\mathrm{C}}$ and $\mathrm{PVY}^{\mathrm{N}}$. Of particular interest in this survey was the incidence of PVYN , the necrotic strain of PVY, and its effect on the quality of seed production in New Zealand. PVY ${ }^{\mathrm{N}}$ was first detected in New Zealand in 1989 (Fletcher 1989) and this strain is known to induce tuber necrosis under New Zealand growing conditions (Fletcher 1996; Fletcher \& Lister 2004; Fomitcheva et al. 2009). $\mathrm{PVY}$ and in particular $\mathrm{PVY}^{\mathrm{N}}$ has become the most serious virus pathogen in potato crops in North America (Gray et al. 2010), Europe and 
South America (Valkonen 2007) and now in parts of Australia (Nigel Crump, VicSPA, personal communication). Previous virus surveys in 1996 (Fletcher et al. 1996), 2002, 2003 and 2004 (Fletcher \& Lister 2004; J.D. Fletcher, unpublished data) have found mean incidences of PVY up to $90 \%$ in earlier years with a downward trend in subsequent surveys. PVY may be transmitted mechanically, vegetatively and by aphid vectors.

In addition to PVY, the survey aimed to determine the incidence of five other viruses, Potato virus X(PVX), Potato virus S (PVS), Potato virus $M(\mathrm{PVM})$, Potato virus A (PVA) and Potato leafroll virus (PLRV) as a further measure of seed and crop health and management. Two strains of PVS are recorded in New Zealand, PVS and PVS ${ }^{\mathrm{A}}$, both of which are mechanically and vegetatively transmitted, but $\mathrm{PVS}^{\mathrm{A}}$ is also aphid transmitted (Fletcher 1996).

Of the other viruses surveyed all may be transmitted vegetatively, all but PLRV may be mechanically transmitted and all apart from PVX may be aphid transmitted.

This paper summarises the results of this survey, which measured potato viruses in the three major potato growing regions of New Zealand.

\section{MATERIALS AND METHODS}

With the cooperation of growers, merchants and processors, 35 potato crops were surveyed in South Auckland, Waikato and Canterbury. This included 16 fresh, 12 process and 7 seed crops. Based on the method used in past surveys (Fletcher et al. 1996), in each crop, 100 leaf samples were randomly collected in a 'W' pattern. Leaves were cool stored prior to use.

The leaves were bulked into 10 lots of 10 leaves and assayed serologically for potato viruses $\mathrm{X}$, Y, S, M, A and PLRV. Double or triple antibody sandwich enzyme-linked immunosorbent assay (ELISA) was performed according to the manufacturer's protocols and indirect ELISA according the method of Fletcher (1996).

Stored sap from any positive PVY group was further tested serologically using specific monoclonal antibodies to determine the strain of PVY present. The presence of $\mathrm{PVY}^{\mathrm{N}}$ was also confirmed by host inoculation of sap from any positive groups each onto individual Nicotiana tabacum plants. $\mathrm{PVY}^{\mathrm{N}}$ is distinguished from other strains by a distinct veinal necrosis symptom on tobacco. Similarly some samples of PVS positive groups were further tested for the strain $\mathrm{PVS}^{\mathrm{A}}$ by inoculation on to individual Chenopodium quinoa plants. $\mathrm{PVS}^{\mathrm{A}}$ is distinguished from PVS by a systemic mosaic symptom in quinoa. Incidence for the five viruses was estimated using a table (Fletcher 1996) derived using the formula of Gibbs \& Gower (1962). Note that not all viruses and strains were measured in all years.

\section{RESULTS}

Full survey results are presented in Table 1,which summarises the number of infected crops and the percentage $(\%)$ incidence of potato viruses $\mathrm{X}, \mathrm{Y}, \mathrm{Y}^{\mathrm{N}}, \mathrm{S}, \mathrm{M}, \mathrm{A}$ and PLRV detected in 35 potato crops. Table 2 summarises the mean incidence of viruses grouped according to crop type: fresh, process and seed.

Figure 1 presents a comparison of mean incidence of four viruses and the strain $\mathrm{PVY}^{\mathrm{N}}$ that were monitored consistently from six surveys completed over the past 20 years.

Six of the seven inoculated isolates of PVY developed veinal necrosis symptoms on tobacco, indicating the presence of $\mathrm{PVY}^{\mathrm{N}}$, which was further confirmed with monoclonal antibody ELISA. PVYO was present in the other crop. Six of seven inoculated isolates of PVS developed systemic mosaic symptoms in C. quinoa, indicating they were PVS ${ }^{\mathrm{A}}$.

Survey results from Table 1 and Figure 1 indicate that PVS is the most widespread of the virus tested for, with 32 of the 35 crops testing positive for this virus. Previous survey results estimated the incidence of PVS in potato crops to be $100 \%$. In this survey, PVS incidence was 100\% in 29 of the PVS positive crops and less than 10\% in the remaining three PVS positive crops. In this survey PVS $^{A}$ was detected in about $80 \%$ of the PVS positive crops based on inoculations on to C. quinoa.

PVM and PVA were present in 12 and 10 crops respectively, with PVM estimated at 100\% 


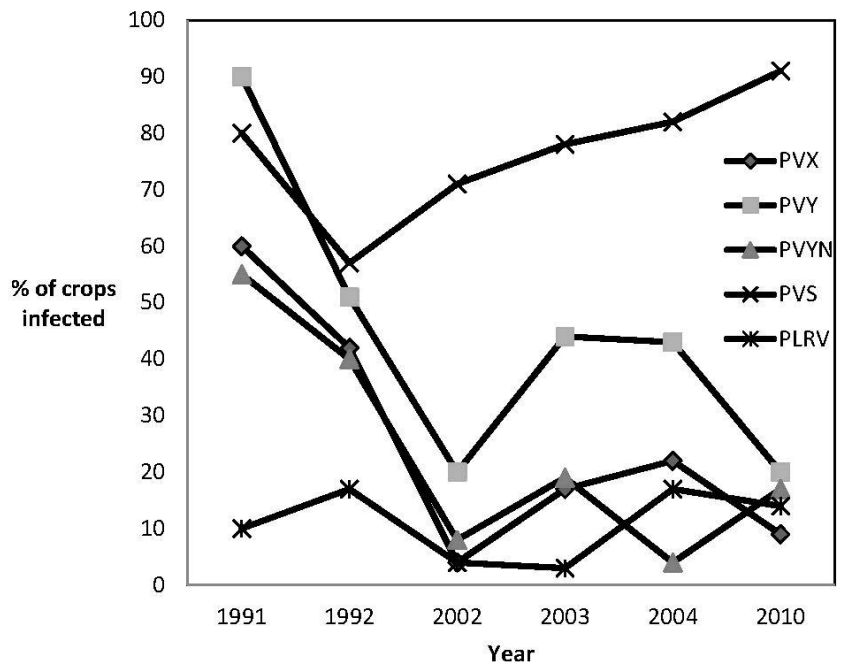

Figure 1 Percentage of crops infected with five viruses (PVX, PVY, PVS, PLRV and the strain PVYN) from six surveys of potato crops completed over 20 years from 1991 to 2011.

incidence in 11 of the crops. PVA incidence, however, was always below 3.5\%. PVY was found in 7 of the 35 crops surveyed and PVYN was present in 6 of the 7 PVY positive crops (17\%) and $\mathrm{PVY}^{\mathrm{O}}$ present in just one of the 7 crops. Within crops, PVY incidence was 100\% in two crops but the remaining five crops had half that incidence or less (1-45\%). PLRV was detected in only 5 of 35 crops surveyed and incidence in the five crops was only 1 to $2 \%$. Similarly PVX was detected in only three crops at very low incidence (1-2\%).

There was no discernible trend of virus incidence between regions.

PVS, PVX, PVY, and PVA were most prevalent in fresh crops (Table 2). PVS, PVM, PLRV and PVA were most prevalent in process crops, with some PVY. PVS was present in later seed generations, with some traces in of PVY in earlier generations. In most crops (25) mixed infections were detected, 10 crops had single virus infections - five each in fresh and seed crops. There was only one seed crop where no viruses were detected.

\section{DISCUSSION}

When surveys were compared over 20 years (Figure 1), the percentage of crops with $\mathrm{PVY}^{\mathrm{N}}$ has continued to trend downwards to $20 \%$. This improvement is likely to be as a result of more effective seed inspection, better roguing and improved control of aphid vectors, (especially as a recent response to tomato potato psyllid). Conversely, over the last two decades there has been a trend for PVS to increase, from 60 to $90 \%$ of surveyed crops, and most crops have an incidence of $100 \%$. The small sample of PVS isolates tested for strain typing indicated $\mathrm{PVS}^{\mathrm{A}}$ was the most common. This might be because this strain occurs in higher concentration in the host and is transmitted efficiently by aphids such as Myzus persicae as well as being transmitted mechanically and by infected seed tuber (Anon. 2000). PVS is not easily rouged because its symptoms are very mild and easily missed. PVS is not regarded by the potato industry as an important concern but its detection can indicate a level of poor quality control in seed production. On the other hand, incidences of PVX, PVY and PLRV have trended downwards over the 20 -year period, to be present in $20 \%$ of crops or less in this survey, and with incidences of below 4\%. Indeed PVX and PLRV seem to have all but disappeared and PVY could be said to be under a degree of control. Of some concern 
Table 1 Number of crops infected and estimated incidences (\%) of potato viruses X, Y, YN , S, M, A and PLRV detected in a survey of 35 fresh $(\mathrm{F})$, process $(\mathrm{P})$ and seed $(\mathrm{S})$ potato crops from Auckland (AK), Waikato (WO), South Canterbury (SC), Mid Canterbury (MC) and North Canterbury (NC) in 2010-11.

\begin{tabular}{|c|c|c|c|c|c|c|c|c|}
\hline Cultivar, type & Region & PVX & $\mathrm{PVY}$ & $\mathrm{PVY}^{\mathrm{N}}$ & PVS & PVM & PVA & PLRV \\
\hline 'Fianna', F & $\mathrm{AK}$ & 0 & 0 & 0 & 100 & 0 & 0 & 0 \\
\hline 'Agria', F & $\mathrm{AK}$ & 0 & 0 & 0 & 100 & 0 & 0 & 0 \\
\hline 'Vivaldi', F & $\mathrm{AK}$ & 0 & 0 & 0 & 100 & 0 & 0 & 0 \\
\hline 'Golden Miracle', F\&P & $\mathrm{AK}$ & 0 & 0 & 0 & 100 & 0 & 1 & 0 \\
\hline 'Draga', F & $\mathrm{AK}$ & 0 & 0 & 0 & 100 & 0 & 0 & 0 \\
\hline 'Moonlight', P & $\mathrm{AK}$ & 0 & 0 & 0 & 3.5 & 0 & 1 & 0 \\
\hline 'Moonlight', F & $\mathrm{AK}$ & 0 & 100 & 100 & $100^{1,2}$ & 0 & 0 & 0 \\
\hline 'Nadine', F & WO & 0 & 0 & 0 & 100 & 0 & 0 & 1 \\
\hline 'Golden Miracle', F & WO & 1 & 4 & 4 & $2^{2}$ & 0 & 1 & 0 \\
\hline 'Agria’, F & WO & 0 & 0 & 0 & 100 & 0 & 2 & 0 \\
\hline 'Moonlight', F & WO & 0 & 15 & 15 & $100^{2}$ & 0 & 0 & 0 \\
\hline 'Lady Rosetta', F & WO & 0 & 0 & 0 & 9 & 0 & 1 & 0 \\
\hline 'Golden Miracle', F & WO & 0 & 0 & 0 & 100 & 0 & 2 & 0 \\
\hline 'Fianna', F & WO & 0 & 0 & 0 & 100 & 0 & 1 & 0 \\
\hline 'Fianna', F & WO & 0 & 0 & 0 & $100^{1}$ & 0 & 0 & 0 \\
\hline 'Russet Burbank', P & $\mathrm{SC}$ & 0 & 0 & 0 & 100 & 100 & 1 & 0 \\
\hline 'Ranger’, P & SC & 0 & $45^{3}$ & 0 & $100^{1,2}$ & 100 & 0 & 0 \\
\hline 'Innovator', P & SC & 0 & 0 & 0 & 100 & 100 & 0 & 0 \\
\hline 'Russet Burbank', P & SC & 0 & 0 & 0 & 100 & 100 & 0 & 0 \\
\hline 'Russet Burbank', P & SC & 0 & 0 & 0 & 100 & 100 & 0 & 0 \\
\hline 'Victoria', P & SC & 0 & 0 & 0 & 100 & 100 & 0 & 0 \\
\hline 'Pentland Dell', F & $\mathrm{MC}$ & 1 & 0 & 0 & 100 & 0 & 3.5 & 0 \\
\hline 'Karaka', F & $\mathrm{MC}$ & 1 & 100 & 100 & $100^{2}$ & 1 & 2 & 0 \\
\hline 'Russet Burbank', P & MC & 0 & 0 & 0 & $100^{2}$ & 100 & 0 & 1 \\
\hline 'Nadine', P & $\mathrm{MC}$ & 0 & 0 & 0 & 100 & 100 & 0 & 0 \\
\hline 'Russet Burbank', P & $\mathrm{MC}$ & 0 & 0 & 0 & 100 & 100 & 0 & 2 \\
\hline 'Russet Burbank', P & $\mathrm{MC}$ & 0 & 0 & 0 & 100 & 100 & 3.5 & 2 \\
\hline 'Moonlight', P & $\mathrm{MC}$ & 0 & 0 & 0 & 100 & 100 & 0 & 1 \\
\hline 'Russet Burbank', S & $\mathrm{MC}$ & 0 & 0 & 0 & 100 & 0 & 0 & 0 \\
\hline 'Bondi', S & $\mathrm{MC}$ & 0 & 0 & 0 & 11 & 0 & 0 & 0 \\
\hline 'Rua', S & $\mathrm{MC}$ & 0 & 1 & 1 & 0 & 0 & 0 & 0 \\
\hline 'Russet Burbank', S & MC & 0 & 0 & 0 & 100 & 0 & 0 & 0 \\
\hline 'Ranger' S & $\mathrm{MC}$ & 0 & 0 & 0 & 100 & 0 & 0 & 0 \\
\hline 'Hermes', S & $\mathrm{NC}$ & 0 & 1 & 1 & 0 & 0 & 0 & 0 \\
\hline 'Bondi', S & $\mathrm{NC}$ & 0 & 0 & 0 & 0 & 0 & 0 & 0 \\
\hline Number of crops infected & & 3 & 7 & 6 & 32 & 12 & 10 & 5 \\
\hline Percentage of crops infected & & 9 & 20 & 17 & 91 & 34 & 29 & 14 \\
\hline Range of incidence & & $0-1$ & $0-100$ & $0-17$ & $0-100$ & $0-100$ & $0-3.5$ & $0-2$ \\
\hline
\end{tabular}

${ }^{1} \mathrm{PVS},{ }^{2} \mathrm{PVS}^{\mathrm{A}},{ }^{3} \mathrm{PVY}$. 
Table 2 Estimated incidences (\%) of potato viruses X, Y, Y ${ }^{\mathrm{N}}, \mathrm{S}, \mathrm{M}, \mathrm{A}$ and PLRV detected in a survey of 16 fresh, 12 process and 7 seed potato crops in 2010-11. Crops are grouped according to crop type: fresh $(\mathrm{F})$, process $(\mathrm{P})$ and seed $(\mathrm{S})$. Generation of seed crop is indicated $(\mathrm{G})$.

\begin{tabular}{|c|c|c|c|c|c|c|c|}
\hline Crop type & PVX & PVY & $\mathrm{PVY}^{\mathrm{N}}$ & PVS & PVM & PVA & PLRV \\
\hline $\mathrm{F}$ & 0 & 0 & 0 & 100 & 0 & 0 & 0 \\
\hline $\mathrm{F}$ & 0 & 0 & 0 & 100 & 0 & 0 & 0 \\
\hline $\mathrm{F}$ & 0 & 0 & 0 & 100 & 0 & 0 & 0 \\
\hline $\mathrm{F} \& \mathrm{P}$ & 0 & 0 & 0 & 100 & 0 & 1 & 0 \\
\hline $\mathrm{F}$ & 0 & 0 & 0 & 100 & 0 & 0 & 0 \\
\hline $\mathrm{F}$ & 0 & 100 & 100 & 100 & 0 & 0 & 0 \\
\hline $\mathrm{F}$ & 0 & 0 & 0 & 100 & 0 & 0 & 1 \\
\hline $\mathrm{F}$ & 1 & 4 & 4 & 2 & 0 & 0 & 0 \\
\hline $\mathrm{F}$ & 0 & 0 & 0 & 100 & 0 & 2 & 0 \\
\hline $\mathrm{F}$ & 0 & 15 & 15 & 100 & 0 & 0 & 0 \\
\hline $\mathrm{F}$ & 0 & 0 & 0 & 9 & 0 & 1 & 0 \\
\hline $\mathrm{F}$ & 0 & 0 & 0 & 100 & 0 & 2 & 0 \\
\hline $\mathrm{F}$ & 0 & 0 & 0 & 100 & 0 & 1 & 0 \\
\hline $\mathrm{F}$ & 0 & 0 & 0 & 100 & 0 & 0 & 0 \\
\hline $\mathrm{F}$ & 1 & 0 & 0 & 100 & 0 & 3.5 & 0 \\
\hline $\mathrm{F}$ & 1 & 100 & 100 & 100 & 1 & 2 & 0 \\
\hline Estimated incidence for 16 fresh crops & 19 & 25 & 25 & 100 & 6 & 43 & 6 \\
\hline $\mathrm{P}$ & 0 & 0 & 0 & 100 & 100 & 1 & 0 \\
\hline $\mathrm{P}$ & 0 & 45 & 0 & 100 & 100 & 0 & 0 \\
\hline $\mathrm{P}$ & 0 & 0 & 0 & 100 & 100 & 0 & 0 \\
\hline $\mathrm{P}$ & 0 & 0 & 0 & 100 & 100 & 0 & 0 \\
\hline $\mathrm{P}$ & 0 & 0 & 0 & 100 & 100 & 0 & 0 \\
\hline $\mathrm{P}$ & 0 & 0 & 0 & 100 & 100 & 0 & 0 \\
\hline $\mathrm{P}$ & 0 & 0 & 0 & 100 & 100 & 0 & 1 \\
\hline $\mathrm{P}$ & 0 & 0 & 0 & 100 & 100 & 0 & 0 \\
\hline $\mathrm{P}$ & 0 & 0 & 0 & 100 & 100 & 0 & 2 \\
\hline $\mathrm{P}$ & 0 & 0 & 0 & 100 & 100 & 3.5 & 2 \\
\hline $\mathrm{P}$ & 0 & 0 & 0 & 100 & 100 & 0 & 1 \\
\hline $\mathrm{P}$ & 0 & 0 & 0 & 3.5 & 0 & 1 & 0 \\
\hline Estimated incidence for 12 process crops & 0 & 8 & 0 & 100 & 91 & 25 & 30 \\
\hline S G1 & 0 & 1 & 1 & 0 & 0 & 0 & 0 \\
\hline S G1 & 0 & 0 & 0 & 0 & 0 & 0 & 0 \\
\hline S G4 & 0 & 1 & 1 & 0 & 0 & 0 & 0 \\
\hline S G6 & 0 & 0 & 0 & 100 & 0 & 0 & 0 \\
\hline S G6 & 0 & 0 & 0 & 100 & 0 & 0 & 0 \\
\hline S G6 & 0 & 0 & 0 & 100 & 0 & 0 & 0 \\
\hline S G6 & 0 & 0 & 0 & 11 & 0 & 0 & 0 \\
\hline Estimated incidence for 7 seed crops & 0 & 28 & 28 & 43 & 0 & 0 & 0 \\
\hline
\end{tabular}


is the apparent increase in the incidence of PVM, a carlavirus related to PVS, that is similarly both mechanically and aphid transmitted and similarly produces only mild field symptoms in potatoes. This virus was previously not thought to be widespread in New Zealand. In 1991-92 it was found in $5-8 \%$ of crops, with incidences below $5 \%$, so it was not surveyed again until now (2010-11). Similarly, PVA, a potyvirus related to PVY, was not detected in 1991 but was found in 1992 in $17 \%$ of crops and is now reasonably widespread, albeit at low incidences. This virus also exhibits mild field symptoms under New Zealand growing conditions.

Further examination of virus incidence within crop types (Table 2) revealed some interesting trends. Viruses appeared absent or rare in early generation seed crops (G1-G4), as would be hoped. PVS was strongly prevalent in only three late-generation seed lines, which were all processing lines. Process seed tubers are often cut before planting because of their size. Cutting seed is known to spread mechanically transmitted viruses (Franc \& Banttari 1984). PVM was largely confined to processing lines, which might support the theory that this virus in particular might spread during seed cutting. A further contributor to virus spread may be the increased movement of spray equipment through crops in response to the TPP outbreak. PVY appeared only in some seed lines and reached highest incidences in a few fresh crops and an occasional process crop. PVA and PLRV appeared scattered among process and fresh crops. No obvious regional differences in virus incidence were observed from this survey.

It is clear from this survey that the virus 'status' of potato crops has changed from those previously recorded. Control of PVX, PVY and PLRV has largely improved over time, whereas the incidences of the carlaviruses PVS and PVM and the potyvirus PVA have increased. Carlaviruses are regarded in New Zealand as causing little effect on the host potato. However, elsewhere in the world, and when in combination with more aggressive viruses such as PVX, PVY and PLRV, yield losses and quality effects are enhanced (Beemster \& de Bokx 1987). Most crops in this survey had PVS plus one or more other virus infections so it would seem likely that there were some yield or quality losses.

The New Zealand potato seed certification programme is presently being reviewed and it is timely that this survey can add weight and direction for some improvements. These might include: greater attention to seed cutting hygiene, improved standards for seed crop isolation from fresh and process crops, more intensive virus testing of early generation seed lines, and more targeted roguing of virus-infected seed lines.

\section{ACKNOWLEDGEMENTS}

I acknowledge funding from The New Zealand Institute for Plant \& Food Research Limited Capability Fund for this survey project. I thank Duncan McLeod, Callum Fletcher, Kerry Hughes, John Stanley, Monty Spencer, Fenton Hazelwood, Keith Watson and Brendan Chapman for their collaboration and allowing me to visit and survey their crops.

\section{REFERENCES}

Anonymous 2000. Potato virus S - Andean strain. www.eppo.org/.../Pest...virus/.../00-7892\%20 DS\%20PVS000.pdf (accessed 10 April 2012).

Beemster ABR, de Bokx JA 1987. Survey of properties and symptoms. Chapter 6. In: de Bokx JA, van der Want JPH ed. Viruses of potatoes and seed-potato production. $2^{\text {nd }}$ edition. Pudoc, Wageningen, The Netherlands. Pp. 84-113.

Fletcher JD 1989. Potato virus - Yn host range and incidence in seed potato crops in New Zealand. New Zealand Journal of Crop and Horticultural Science 17: 259-263.

Fletcher JD, Lewthwaite SL, Boddington HJ, Nott HM, Wood RJ 1996. Virus disease surveys of ware potato crops, Franklin County, North Island, New Zealand. New Zealand Journal of Crop and Horticultural Science 24: 7-12.

Fletcher JD 1996. Potato virus $S^{A}$ - characteristics of an isolate from New Zealand. New Zealand Journal of Crop and Horticultural Science 24: 335-339. 
Fletcher JD, Lister RA 2004. PVY NTN in New Zealand potato crops. Potato Research 46: 190 (Abstract).

Franc GD, Banttari EE 1984. The transmission of potato virus $S$ by the cutting knife and retention time of infectious PVS on common surfaces. American Potato Journal 61: 253260.

Fomitcheva VW, Fletcher JD, Schubert J 2009. Potato virus $\mathrm{Y}$ strain spectrum in New Zealand - absence of recombinant $\mathrm{N}: \mathrm{O}$. Journal of Phytopathology 157: 507-510.

Gibbs AJ, Gower JC 1960. The use of a multiple transfer method in plant virus transmission studies - some statistical points arising in the analysis of results. Annals of Applied Biology 48: 75-83.
Gray S, De Boer S, Lorenzen J, Karasev A, Whitworth J, Nolte P, Singh R, Boucher A, Xu H 2010. Potato virus Y: An evolving concern for potato crops in the United States and Canada. Plant Disease 94: 1384-1397.

Potatoes New Zealand Industry Profile 2011. http://www.potatoesnz.co.nz/Overview/OurIndustry/Industry-profile.htm December (accessed 10 April 2012).

Valkonen JPT 2007. Viruses: economic losses and biotechnological potential. Chapter 28 . In: Vreugdenhil D ed. Potato biology and biotechnology: advances and perspectives. Pp. 619-642. 